\title{
Pengaruh Model Pembelajaran STAD Berbantu Media Film Situs Astana Gede Kawali Terhadap Kesadaran Sejarah Siswa (Studi Penelitian Kuasi Eksperimen Di Kelas X SMAN 1 Baregbeg)
}

Yadi Kusmayadi dan Aan Suryana

Program Studi Pendidikan Sejarah, FKIP, Universitas Galuh Ciamis

\begin{abstract}
Abstrak
Penelitian ini berjudul Pengaruh Model Pembelajaran Student Team's Achievment Division (STAD) Berbantu Media Film Situs Astana Gede Kawali Terhadap Kesadaran Sejarah Siswa (Studi Penelitian Kuasi Eksperimen Di Kelas X SMAN 1 Baregbeg). Tujuan penelitian ini adalah untuk menemukan perbedaan pengaruh model pembelajaran kooperatif Student Teams Achievment Division (STAD) berbantu media film situs Astana Gede Kawali terhadap kesadaran sejarah siswa pada mata pelajaran sejarah, serta menemukan pengaruh kesadaran sejarah terhadap hasil belajar siswa. Penelitian ini menggunakan metode kuasi eksperimen dengan menggunakan Desain Kelompok Kontrol Non-ekuivalen. Penelitian dilaksanakan di SMAN 1 Baregbeg. Teknik pengambilan sampel yaitu pemilihan secara acak atau random sampling dengan cara pengundian. Sampel penelitian adalah kelas X di SMAN 1 Baregbeg dan kelas XIPA 1 dan X IPA 2. Teknik pengumpulan data menggunakan tes dan observasi. Hasil penelitian menunjukan bahwa Pertama, terdapat perbedaan yang signifikan hasil belajar dan kesadaran sejarah siswa yang menggunakan model pembelajaran kooperatif STAD berbantuan media film Situs Astana Gede Kawali dengan siswa yang tidak menggunakan model pembelajaran kooperatif STAD berbantuan media film, yaitu hasil belajar rata-rata 76,19 untuk kelas eksperimen dan 69,29 untuk kelas kontrol. Kedua, terdapat pengaruh kesadaran sejarah dan hasil belajar siswa $80 \%$.
\end{abstract}

Kata Kunci: STAD, Film, Astana Gede Kawali

\section{Pendahuluan}

Pendidikan sejarah merupakan suatu komponen yang penting dalam pendidikan suatu bangsa khususnya bagi bangsa Indonesia, karena dengan pendidikan sejarah seseorang akan mengetahui dan memahami sejarah dari bangsa dan negaranya sendiri. Selain itu, menurut Hasan pendidikan sejarah dianggap suatu komponen yang penting karena, adanya keyakinan bahwa materi pendidikan sejarah mampu mengembangkan sifat dan karakter generasi muda bangsa. Hal itu terjadi karena melalui pendidikan sejarah mereka memahami bagaimana bangsa ini lahir dan berkembang, permasalahan yang dihadapi dalam kehidupan bangsa masa lalu, masa kini, dan bagaimana menyelesaikan berbagai masalah tersebut dan bagaimana mereka belajar dari pengalaman masa lampau tersebut untuk membentuk kehidupan masa depan menjadi lebih baik dan berdasarkan sifat dan karakter utama bangsa. Oleh karena itu, pendidikan sejarah memiliki fungsi yang strategis dalam mengembangkan jiwa dan karakter bangsa dan membangun kehidupan masa depan yang lebih baik.

Collingwood (dalam Wiyanarti: 1956) menyatakan bahwa pembentuk identitas nasional suatu bangsa tiada lain 
adalah sejarah. Bahkan dikatakan bahwa pengetahuan sejarah selain sangat fundamental dalam pembentukan identitas nasional juga sumber inspirasi yang sarat makna dalam pengembangan kesadaran sejarah para generasi muda.

Soedjatmoko (1995) mengatakan bahwa kesadaran sejarah merupakan orientasi intelektual dan sikap jiwa yang perlu untuk memahami secara tepat faham kepribadian nasional. Lebih lanjut dikatakan bahwa kesadaran sejarah akan mampu membimbing manusia kepada pengertian mengenai diri sendiri sebagai bangsa. Memahami betapa pentingnya kesadaran sejarah, maka pengembangan pendidikan sejarah merupakan tuntutan untuk melahirkan generasi bijaksana yang mampu menyelesaikan permasalahan bangsa dengan bijaksana. Menurut Aman pelajaran sejarah juga mempunyai fungsi sosio-kultural, membangkitkan kesadaran historis.

Berdasarkan kesadaran historis dibentuk kesadaran nasional. Hal ini membangkitkan inspirasi dan aspirasi kepada generasi muda bagi pengabdian kepada negara dengan penuh dedikasi dan kesediaan berkorban. Sejarah nasional perlu menimbulkan kebanggaan nasional (nationalpride), harga diri, dan rasa swadaya. Dengan demikian sangat jelas bahwa pelajaran sejarah tidak semata-mata memberi pengetahuan, fakta, dan kronologi. Realitasnya, pentingnya pendidikan sejarah yang dikemukakan di atas tidak sesuai dengan kenyataan yang terdapat di dunia pendidikan saat ini. Hal ini senada dengan pendapat yang dikemukakan Hasan bahwa alih-alih memberikan kesempatan untuk mengembangkan kemampuan yang dikemukakan di atas, suatu kenyataan yang menyedihkan bahkan dunia pendidikan sejarah dianggap sebagai sesuatu yang suram, tak bermakna, penuh dengan beban hafalan yang tak mampu mengembangkan kemampuan berfikir kritis, tak berkaitan dengan realita kehidupan, tidak membangkitkan rasa ingin tahu dan kemampuan memenuhi rasa ingin tahu tersebut (study skills) serta mengembangkan kebangsaan positif.

Oleh karena itu, pendidikan sejarah tidak dianggap sebagai sesuatu yang berhasil menjalankan fungsinya dalam mengembangkan potensi kemanusiaan peserta didik dan bagi penentu kebijakan memberikan kesempatan yang besar untuk memposisikan pendidikan sejarah hanya bagi mereka yang tertarik untuk menjadi sejarawan di kemudian hari.

Hal ini senada dengan yang diungkapkan Subakti (2010) bahwa pembelajaran sejarah saat ini menghadapi banyak persoalan. Persoalan itu mencakup lemahnya penggunaan teori, miskinnya imajinasi, acuan buku teks dan kurikulum yang state oriented, serta kecenderungan untuk tidak memperhatikan fenomena 
globalisasi berikut latar belakang historisnya. Lemahnya penggunaan teori dalam kajian sejarah memang ada benarnya, karena sejarah memang tidak mempunyai teori. Sejarah meminta bantuan teori-teori dari disiplin sosial lainnya dalam setiap kajiannya. Misalnya teori-teori sosiologi, antropologi, psikologi, politik, dan sebagainya. Melalui teori-teori tersebut kajian sejarah akan lebih kaya makna. Hanya kemampuan guru-guru sejarah dalam meramu sajian sejarah dirasa kurang memadukan disiplin-disiplin sosial lainnya dalam kajian sejarah.

Guru dirasa kurang dalam menggunakan pendekatan interdisipliner dalam kajian sejarah. Dalam proses pembelajaran sejarah, masih banyak guru menggunakan paradigma konvensional, yaitu paradigma guru menjelaskan - murid mendengarkan. Metode pembelajaran sejarah semacam ini telah menjadikan pelajaran sejarah membosankan. Kemudian tidak memberikan sentuhan emosional karena siswa merasa tidak terlibat aktif di dalam proses pembelajarannya.

Sementara paradigma siswa aktif mengkonstruksi makna guru membantu merupakan dua paradigma dalam proses belajar-mengajar sejarah yang sangat berbeda satu sama lain. Paradigma ini dianggap sulit diterapkan dan membingungkan guru serta siswa. Di samping itu, metode pembelajaran yang kaku, akan berakibat buruk untuk jangka waktu yang panjang dan berpotensi memunculkan generasi yang mengalami amnesia (lupa atau melupakan sejarah) bangsa sendiri. Selain itu, dapat dilihat dari hasil penelitian yang dilakukan oleh Arif (dalam Pajriah, 2012) menunjukkan bahwa pendidikan sejarah masih diselenggarakan secara ala kadarnya, yakni dengan menggunakan metode konvensional seperti metode ceramah, penugasan, dan sejenisnya. Dalam hal ini guru menyampaikan materi secara monoton, yaitu ceramah dan biasanya minim penggunaan media. Sehingga siswa menjadi pasif dan akhirnya merasa enggan untuk belajar sejarah.

Berbeda dengan pelajaran eksakta, matematika misalnya, meskipun metode yang digunakan adalah ceramah, tetapi siswa diajak untuk berfikir dalam mencari pemecahan masalah. Sehingga siswa merasa terlibat langsung dalam proses pembelajaran. Melihat kondisi tersebut, maka perlu diterapkan suatu sistem pembelajaran yang lebih banyak menuntut siswa untuk lebih aktif dalam kegiatan pembelajaran.

Oleh karena aspek terpenting bagi guru sejarah dalam menghadapi perubahan berbagai bidang yang cukup pesat itu, adalah merubah pola pengajaran sejarah yang mampu beradaptasi dengan situasi baru dan menunjang pendidikan yang bersifat kemanusiaan. Artinya guru perlu mengembangkan penggunaan model dan 
media yang memberikan kemudahan bagi siswa untuk memahami materi yang diajarkan, sehingga siswa tertarik untuk belajar sejarah. Guru harus memiliki kompetensi dalam penggunaan model pembelajaran. Model pembelajaran merupakan pola yang digunakan sebagai pedoman merencanakan pembelajaran di kelas/tutorial. Tujuannya membantu guru menyampaikan informasi kepada siswa, sehingga dengan penggunaan model tersebut siswa lebih mengerti dan memahami materi yang disampaikan.

Penelitian ini menggunakan model pembelajaran kooperatif tipe STAD berbantu media film Situs Astana Gede Kawali. Situs ini merupakan peninggalan Kerajaan Galuh yang terletak di Kawali Kabupaten Ciamis. Kemudian diintegrasikan peristiwa sejarah yang dekat dengan lingkungan siswa dalam kegiatan belajar yang disesuaikan dengan kurikulum di sekolah. Adanya media tersebut, maka kesadaran sejarah siswa akan meningkat. Tujuan penelitian ini bagaimana pengaruh model pembelajaran STAD berbantu media film situs Astana Gede Kawali terhadap kesadaran sejarah SMAN 1 Baregbeg Ciamis.

\section{Tinjauan Pustaka}

\section{A. Model Pembelajaran Kooperatif STAD}

Model pembelajaran merupakan landasan praktik pembelajaran. Model pembelajaran dapat diartikan juga sebagai pola yang digunakan untuk penyusunan kurikulum, mengatur materi, dan memberi petunjuk kepada guru di kelas. Joyce (Trianto, 2007: 5) menyatakan bahwa model pembelajaran adalah suatu perencanaan atau suatu pola yang digunakan sebagai pedoman dalam melaksanakan pembelajaran di kelas atau pembelajaran tutorial dan untuk menentukan perangkat pembelajaran termasuk didalamnya buku-buku, film, komputer, kurikulum dan lain-lain.

Dalam kegiatan penelitian model pembelajaran yang digunakan adalah model pembelajaran kooperatif. Pembelajaran kooperatif dapat menciptakan suasana ruang kelas yang terbuka. Hal tersebut disebabkan pembelajaran ini mampu membangun keberagaman dan mendorong koneksi antar siswa. Salah satu contoh model pembelajaran kooperatif adalah model pembelajaran STAD.

STAD (Student Team Achievement Division) adalah salah satu model pembelajaran kooperatif yang mempunyai prinsip bahwa siswa harus belajar bersama dan bertanggung jawab atas pembelajaran sendiri dan pembelajaran teman satu kelompoknya, membuat kelompok heterogen (4-5 orang) berdasarkan kemampuan, gender, ras dan etnis, adanya sajian presentasi kelompok sehingga terjadi diskusi kelas, kuis individual dan 
membuat skor perkembangan tiap siswa atau tiap kelompok, kemudian mengumumkan rekor tim dan individual serta memberikan reward. Model ini juga menekankan pentingnya tujuan dan kesuksesan kelompok yang dapat dicapai, hanya jika semua anggota kelompok benarbenar mempelajari materi yang ditugaskan (Huda, 2011: 114-115). Landasan filosofis model pembelajaran kooperatif adalah konstruktivisme. Menurut Suparno, paham konstruktivistik pengetahuan merupakan konstruksi (bentukan) dari orang yang mengenal sesuatu (skemata).

Pengetahuan tidak bisa ditransfer dari guru kepada orang lain, karena setiap orang mempunyai skema sendiri tentang apa yang diketahuinya. Pembentukan pengetahuan merupakan proses kognitif tempat terjadi proses asimilasi dan akomodasi untuk mencapai keseimbangan sehingga terbentuk suatu skema yang baru (Thabrani \& Mustofa, 2011:107-108).

Model STAD mempunyai beberapa kelebihan, antara lain para siswa bekerja bersama-sama dalam belajar dan bertanggung jawab terhadap belajar teman-temannya dalam tim dan juga dirinya sendiri, serta adanya penghargaan kelompok yang mampu mendorong para siswa untuk kompak, setiap siswa mendapat kesempatan yang sama untuk menunjang timnya mendapat nilai yang maksimum, sehingga termotivasi untuk belajar. Lebih jauh, Slavin memaparkan bahwa gagasan utama dibelakang STAD adalah memacu siswa agar saling mendorong dan membantu satu sama lain untuk menguasai keterampilan yang diajarkan guru (Rusman, 2012: 214).

Adapun langkah pembelajaran kooperatif STAD sebagai berikut:

1. Penyampaian Tujuan dan Motivasi

2. Pembagian Kelompok

3. Persentasi dari Guru

4. Kegiatan Belajar Dalam Tim

5. Kuis (Evaluasi)

6. Penghargaan Prestasi Team (Rusman, 2012).

\section{B. Media Film}

Pada awal sejarah pendidikan, guru merupakan sumber utama untuk memperoleh pelajaran. Perkembangannya, sumber belajar kemudian bertambah dengan adanya buku. Pada akhir tahun 1950, teori komunikasi mulai mempengaruhi penggunaan alat audio visual. Alat audio visual bukan hanya dipandang sebagai alat bantu guru saja, tetapi berfungsi sebagai penyalur pesan belajar (Aqib, 2013: 49-50).

Berbeda dengan yang lain, $N E A$ (National Education Association) memberikan batasan tentang media. Media adalah bentuk komunikasi, baik tercetak maupun audio visual serta peralatannya. Media hendaknya dapat dimanipulasi, dapat dilihat, didengar, dan dibaca (Sadiman dan Rahardjo, 1993: 6). Pemilihan media juga merupakan bagian 
integral dari proses perencanaan pembelajaran. Media yang dimaksud adalah media yang benar-benar membantu siswa mencapai tujuan pelajaran (Anderson, 1987: 2). Inti pengertian tersebut dapat disimpulkan bahwa media adalah pengantar yang digunakan pendidik untuk menyalurkan pesan dan memberikan rangsangan kepada siswa supaya mereka memperoleh pengetahuan, keterampilan, maupun sikap yang diperoleh setelah belajar. Dalam hal ini media memiliki fungsi untuk memudahkan guru menyampaikan informasi kepada siswa.

\section{Situs Astana Gede Kawali}

Menurut William Haviland (dalam Warsito, 2012: 25) mengatakan bahwa tempat dimana ditemukan peninggalanpeninggalan arkeologi di kediaman makhluk manusia pada zaman dahulu, dikenal dengan nama situs. Situs biasanya ditentukan berdasarkan survey suatu daerah. Salah satu situs peninggalan kerajaan Sunda Galuh di Kawali, yaitu Situs Astana Gede Kawali yang berada di Kawali, Kabupaten Ciamis Jawa Barat.

Astana Gede Kawali merupakan peninggalan purbakala yang berupa Prasasti kerajaan/peninggalan sejarah di bawah pemerintahan Prabu Wastukancana dengan keratonnya bernama Surawisesa. Di Astana Gede Kawali terdapat 6 buah prasasti yang semuanya merupakan peninggalan kerajaan tersebut, dan telah memiliki petunjuk tentang keberadaan
Situs Astana Gede Kawali. Oleh sebab itu, patut dijaga, dipelihara dan dilestarikan sisa peninggalan di kompleks Astana Gede Kawali, berupa Menhir, Lingga, Yoni di samping prasasti yang baru ditemukan tahun 1995 (Soedarmo, 2011: 69).

\section{Kesadaran Sejarah}

Menurut Kartodirdjo (1993: 50) dalam Aman, sejarah merupakan cerita tentang pengalaman kolektif suatu komunitas atau nasion di masa lampau. Pada pribadi pengalaman membentuk kepribadian seseorang dan sekaligus menentukan identitasnya. Proses serupa terjadi pada kolektivitas, yakni pengalaman kolektif atau sejarahnya yang membentuk kepribadian nasional dan sekaligus identitas nasionalnya.

Bangsa yang tidak mengenal sejarahnya diibaratkan seorang individu yang telah kehilangan memorinya, ialah orang yang pikun atau sakit jiwa, maka dia kehilangan kepribadian atau identitasnya (Allan Nevin dalam Maarif, 2006: 121). Aman (2014: 26) mengemukakan sejarah adalah jembatan penghubung masa silam dan masa kini, dan sebagai petunjuk ke arah masa depan.

Untuk sampai pada taraf wujud perilaku, perlu ditumbuhkan kesadaran sejarah sebagaimana dijelaskan oleh Soedjatmoko (1984: 67):

...Suatu orientasi intelektual, suatu sikap jiwa yang perlu memahami secara tepat faham kepribadian 
nasional. Kesadaran sejarah menuntun manusia pada pengertian mengenal diri sendiri sebagai bangsa, kepada self understanding of nation, kepada sangkan paran suatu bangsa, kepada persoalan what we are, what we are what we are...

Dengan demikian, kesadaran sejarah tidak lain dari kondisi kejiwaan yang menunjukkan tingkat penghayatan makna dan hakekat sejarah bagi masa kini dan masa yang akan datang, serta menyadari dasar pokok bagi berfungsinya makna sejarah dalam proses pendidikan.

\section{Metode Penelitian}

Metode yang digunakan penelitian ini adalah kuasi eksperimen. Metode ini akan menemukan kepastian untuk memperoleh informasi tentang pengaruh model Student Teams Achievement Division berbantu media film situs Astana Gede Kawali terhadap kesadaran sejarah siswa (Sugiyono, 2012: 73).

Langkah metode penelitian kuasi eksperimen adalah (a) menelaah kepustakaan, (b) merumuskan masalah, (c) merumuskan hipotesis, (d) mendefinisikan pengertian dasar dan variabel utama (e) menyusun rancangan penelitian melakukan eksperimen variabel utama, (e) menyusun rancangan penelitian, melakukan eksperimen, (g) mengatur data kasar untuk mempermudah analisis selanjutnya, (h) menentukan batas penerimaan atau penolakan hasil, dan (i) menginterpretasikan hasil (Ghufron, 2008).
Adapun desain penelitian yang digunakan adalah non-equivalent control group design.

\section{Hasil Dan Pembahasan}

\section{A. Perbedaan Pengaruh Model Pembelajaran STAD Berbantu Media Film Situs Astana Gede Kawali Terhadap Kesadaran Sejarah}

\section{Kelas Eksperimen}

Seperti yang telah dijelaskan sebelumnya bahwa tujuan penelitian ini adalah untuk menemukan perbedaan pengaruh model pembelajaran kooperatif STAD berbantu media film Situs Astana Gede Kawali terhadap kesadaran sejarah siswa. Data yang dianalisis, yaitu data hasil belajar sejarah siswa dan kesadaran sejarah. Data tersebut diperoleh dari hasil pretes tdan posttest pada materi Kerajaan Hindu-Budha di Indonesia, serta penyebaran angket. Penelitian ini dilaksanakan di kelas X IPA 1 SMA N 1 Baregbeg sebagai kelas eksperimen dan kelas X IPA 2 sebagai kelas kontrol. Sesuai kesepakatan dengan guru sejarah, maka observasi pertama dilaksanakan pada hari Kamis bulan Juli 2018 jam 10.15 .

Dengan tujuan menemukan perbedaan pengaruh model pembelajaran kooperatif STAD berbantuan media fil Situs Astana Gede Kawali terhadap kesadaran sejarah siswa. Sebelumnya, telah mendiskusikan mengenai RPP, model dan media pembelajaran yang akan digunakan. Model pembelajaran kooperatif STAD berbantuan media film Situs Astana Gede Kawali di kelas eksperimen dilaksanakan 
sebanyak dua kali pertemuan. Pada pertemuan pertama, sebelum kegiatan pembelajaran dimulai, guru memberikan pretest kepada siswa sebanyak 20 soal pilihan ganda dan angket kesadaran sejarah sebanyak 20 butir. Waktu yang diberikan, yaitu selama 20 menit. Selanjutnya, guru menyampaikan tujuan dan motivasi belajar kepada siswa, sedangkan siswa mendengarkan. Kemudian, mengecek kehadiran siswa kelas X IPA 1 yang berjumlah 21 orang, namun pada pertemuan pertama satu orang tidak hadir, karena sakit.

Selanjutnya, guru menyampaikan garis besar materi pembelajaran mengenai proses masuknya agama Hindu-Budha ke Indonesia yang dibarengi dengan media film Situs Astana Gede Kawali. Pada pembahasan ini guru menyampaikan materi tentang teori masuknya HinduBudha ke Indonesia yang terdiri dari teori Ksatria, Waisya, Brahmana, dan arus balik. Selain itu, dijelaskan pula mengenai peninggalan-peninggalan dari zaman Hindu-Budha yang masih bisa dijumpai pada saat ini, seperti Candi Borobudur dan Candi Prambanan yang terletak di Provinsi Jawa Tengah.

Selanjutnya, siswa juga diajak untuk memahami tentang kerajaan yang bercorak Hindu yang pernah ada di kabupaten Ciamis, yaitu kerajaan Galuh. Kerajaan Galuh merupakan sebuah kerajaan yang didirikan oleh Wretikandayun, sekitar abad ke 7. Salah satu peninggalannya adalah berupa situs yang terletak di Kawali, yang diberi nama Situs Astana Gede Kawali. Di dalamnya terdapat beberapa tinggalan arkeologis berupa prasasti yang berjumlah 6 buah, batu bergores, batu kursi, batu pangeunteungan, dan lain-lain (Herlina, 2017: 8-23). Setelah itu, siswa dibagi menjadi empat kelompok, yaitu kelompok I terdiri dari Ravena Agustina, Rahayu, Imas Rosmiatin, Fina Pebrianti, dan Rakha Ahmd W. Kelompok II terdiri dari: Elsa, Rini, Laila, Vania, Gilang, dan Fauzi. Kelompok III terdiri dari: Salsa Bunga, Cici Hikmah, Fedra Y, dan Ira R. Kelompok IV terdiri dari: Regina Maharani, Nandha R, Tia Evi Y, Dwi Mustikawati, dan M. Abdan S.

Hal ini sesuai dengan langkah pembelajaran kooperatif STAD yang terdiri dari enam langkah menurut Rusman (dalam Suryana, 2015: 21-24), yaitu penyampaian tujuan dan motivasi, pembagian kelompok, presentasi dari guru, kegiatan belajar dalam tim, kuis (evaluasi), dan penghargaan prestasi tim. Tugas setiap kelompok adalah menganalisis film yang telah ditayangkan. Setelah setiap kelompok selesai mengerjakan tugas yang diberikan, kemudian tugas tersebut dikumpulkan.

Kegiatan pembelajaran ditutup oleh guru dengan menarik kesimpulan dari materi yang telah disampaikan serta mempersiapkan untuk materi selanjutnya. Pada pertemuan kedua, hari Kamis bulan Agustus 2018, guru melaksanakan kegiatan 
pembelajaran dengan menggunakan model pembelajaran kooperatif STAD berbantu media film Situs Astana Gede Kawali dengan materi Kerajaan Hindu-Budha di Indonesia. Selama kegiatan pembelajaran, ketika guru menyampaikan materi dengan model pembelajaran STAD berbantu media film, siswa dengan semangat mengikuti kegiatan pembelajaran. Karena biasanya kegiatan pembelajaran hanya dilakukan dengan menggunakan metode ceramah dan belum pernah menggunakan media film, khususnya film yang berkaitan dengan sejarah lokal yang ada disekitar siswa.

\section{Kegiatan}

pembelajaran

dilaksanakan seperti pada pertemuan pertama dengan mengikuti langkahlangkah dari model pembelajaran STAD. Seperti biasa guru masuk ke dalam kelas dan mengucapkan salam. Setelah itu, untuk mengefektifkan waktu guru menyampaikan tujuan dan motivasi belajar kepada siswa, mengecek daftar hadir, dan selanjutnya menyampaikan garis besar materi tentang kerajaan Hindu-Budha di Indonesia, dengan dibarengi media film Situs Astana Gede Kawali.

Pada kegiatan pembelajaran ini, guru menyampaikan contoh-contoh kerajaan yang bercorak Hindu-Budha yang ada di Indonesia. Seperti kerajaan Kutai, Tarumanegara, Majapahit, dan Galuh merupakan kerajaan yang bercorak Hindu. Sedangkan kerajaan Singosari dan Kalingga adalah salah satu contoh kerajaan bercorak
Budha yang ada di Indonesia. Kemudian, guru menjelaskan bahwa di kabupaten Ciamis pernah berdiri sebuah kerajaan yang cukup besar, yaitu kerajaan Galuh yang dikuatkan dengan penemuan bendabenda peninggalan bersejarah yang diyakini memiliki hubungan dengan kerajaan tersebut. Salah satunya, situs Astana Gede Kawali di Kawali Kabupaten Ciamis. Di dalamnya terdapat beberapa tinggalan arkeologis berupa prasasti yang berjumlah 6 buah dengan masing-masing memiliki makna yang berbeda.

Selanjutnya, siswa melaksanakan diskusi kelompok dan bekerja sesuai dengan tugasnya masing-masing. Kelompok yang ada masih sesuai dengan kelompok yang dibentuk pada pertemuan pertama. Setelah selesai, setiap kelompok menyerahkan tugas yang telah diberikan dan guru melakukan evaluasi. Namun, pada pertemuan ke dua ada perbedaan dengan pertemuan pertama, yaitu sebelum kegiatan pembelajaran ditutup siswa diberikan posttest dan angket.

Waktu yang diberikan untuk pengerjaan soal dan angket selama 20 menit dengan soal sama seperti kegiatan pretest. Setelah selesai, kegiatan pembelajaran ditutup dengan kesimpulan dari materi yang sudah disampaikan. Kegiatan pembelajaran dengan menampilkan media film Situs Astana Gede Kawali siswa terlihat sangat antusias dan merasa senang. Hal ini senada dengan 
pendapat Hamalik (dalam Suryana, 2015: 28) yang menyatakan bahwa pemakaian media pembelajaran dalam proses belajar mengajar dapat membangkitkan keinginan dan minat yang baru, membangkitkan motivasi, dan rangsangan kegiatan belajar, bahkan membawa pengaruh-pengaruh psikologis terhadap siswa.

\section{Kelas Kontrol}

Observasi pada kelas kontrol dilaksanakan pada hari Kamis tanggal 3 Agustus 2018 di SMA N 1 Baregbeg kelas X IPA 2. Materi pelajaran sejarah dengan menggunakan metode ceramah dan diskusi tanpa menggunakan model pembelajaran STAD berbantu media film Situs Astana Gede Kawali.

Pada awal kegiatan pembelajaran guru menyampaikan tujuan pembelajaran serta mengecek kehadiran siswa yang berjumlah 21 orang. Sebelumnya siswa diberikan pretest sebanyak 20 butir soal pilihan ganda dan 20 butir angket kesadaran sejarah. Selanjutnya, dengan menggunakan metode ceramah guru menyampaikan materi tentang Proses Masuknya Agama Hindu-Budha ke Indonesia serta Kerajaan Hindu-Budha di Indonesia.

Kemudian siswa, diminta untuk berdiskusi tentang materi yang sudah dijelaskan khususnya tentang kerajaan Hindu yang pernah ada di kabupaten Ciamis, yaitu kerajaan Galuh. Sebelum kegiatan pembelajaran berakhir siswa pun diberikan posttes dengan soal dan angket yang sama seperti pada pretest. Pada kegiatan penutup guru menarik kesimpulan dari materi yang sudah disampaikan.

\section{Hasil Belajar Dan Angket}

Sebelum ada perlakuan baik kelas eksperimen maupun kelas kontrol samasama menerima tes pembelajaran sejarah yaitu pretest yang diberikan dengan tujuan untuk mengetahui pengetahuan awal siswa sebelum diberikan perlakuan. Untuk itu, skor penelitian dianalisis dengan menguji normalitas, homogenitas, dan uji t melalui program SPSS 16.

Skor rata-rata pretest kelas eksperimen 41,67 dan pretest kelas kontrol adalah 40,71. Skor posttest kelas eksperimen 76,19 dan posttest kelas kontrol sebesar 69,29. Data tersebut dapat dilihat pada tabel 5.3 di bawah ini:

Tabel 1. Skor rerata kelas eksperimen dan kontrol

\begin{tabular}{|l|c|c|}
\hline $\begin{array}{c}\text { Skor Rata- } \\
\text { Rata }\end{array}$ & $\begin{array}{c}\text { Kelas } \\
\text { Eksperimen }\end{array}$ & $\begin{array}{c}\text { Kelas } \\
\text { Kontrol }\end{array}$ \\
\hline Pretest & 41,67 & 40,71 \\
\hline Posttest & 76,19 & 69,29 \\
\hline
\end{tabular}

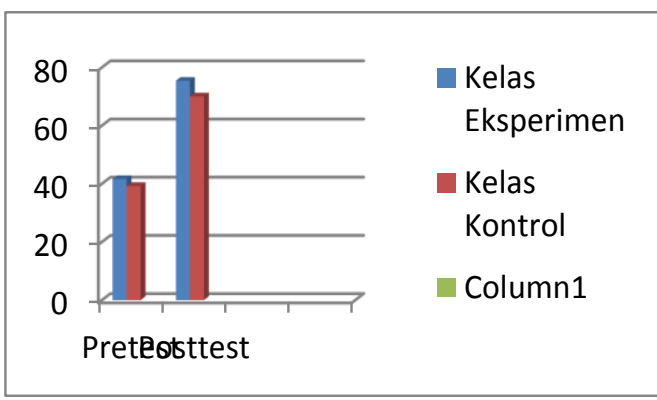

Gambar 1. Perbandingan Hasil Pretest dan Posttest Kelas Eksperimen dan Kelas Kontrol 
Kegiatan penelitian ini dilaksanakan di SMA N 1 Baregbeg di kelas $\mathrm{X}$, yaitu X IPA 1 sebagai kelas eksperimen dan X IPA 2 sebagai kelas kontrol. Sampel penelitian berjumlah 42 siswa, 21 siswa di kelas eksperimen dan 21 siswa di kelas kontrol. Kelas X IPA 1 sebagai kelas eksperimen melakukan kegiatan pembelajaran sejarah dengan menggunakan model pembelajaran kooperatif STAD berbantuan media film Situs Astana Gede Kawali. Materi pada penelitian ini adalah Kerajaan Hindu-Budha di Indonesia. Penelitian ini dilakukan untuk menemukan perbedaan pengaruh model pembelajaran kooperatif STAD berbantuan media film Situs Astana Gede Kawali terhadap kesadaran sejarah.

Untuk mengetahui hal tersebut pada kedua kelompok yaitu eksperimen dan kontrol, maka diberikan perlakuan dengan menggunakan media dan model pembelajaran yang berbeda. Hasil penelitian yang diuraikan adalah hasil analisis data dari pretest dan posttest, uji normalitas data, serta uji homogenitas data. Analisis data menggunakan bantuan program SPSS versi 16. Berikut data hasil pretest dan posttest:

\section{a) Uji normalitas}

Uji normalitas digunakan untuk mengetahui apakah data yang diperoleh berdistribusi normal atau tidak dengan taraf signifikansi 5\%. Perumusan hipotesis yang digunakan dalam uji normalitas data adalah sebagai berikut:

$\mathrm{H}_{0 \text { : }}$ data berasal dari populasi berdistribusi normal

$\mathrm{H}_{1:}$ data berasal dari populasi berdistribusi tidak normal

Untuk kriteria pengujiannya adalah jika nilai signifikansi pengujiannya $\geq 0,05$ maka $\mathrm{H}_{0}$ diterima. Jika nilai signifikansi pengujian $\leq 0,05$ maka $\mathrm{H}_{0}$ ditolak.

Tabel 2. Hasil Uji Normalitas Data Pretest Kelas Eksperimen dan Kelas Kontrol

\begin{tabular}{|c|c|c|c|c|}
\hline Kelas & Sig & A & Keputusan & Ket. \\
\hline Eksperimen & 0,075 & 0,05 & Hoditerima & $\begin{array}{c}\text { Berdistri- } \\
\text { busi Normal }\end{array}$ \\
\hline Kontrol & 0,058 & 0,05 & $\mathrm{H}_{0}$ diterima & $\begin{array}{c}\text { Berdistri- } \\
\text { busi Normal }\end{array}$ \\
\hline
\end{tabular}

Berdasarkan perhitungan uji

normalitas di atas hasil pretest pada kelas eksperimen dengan jumlah sampel sebanyak 21 orang siswa, diperoleh nilai sig $=0,075>0,05$ jadi $\mathrm{H}_{0}$ diterima, maka data pretest kelas eksperimen berdistribusi normal. Sedangkan untuk kelas kontrol diperoleh nilai $\operatorname{sig} 0,058 \geq 0,05$. Jadi $\mathrm{H}_{0}$ diterima, maka data pretest untuk kelas kontrol berdistribusi normal.

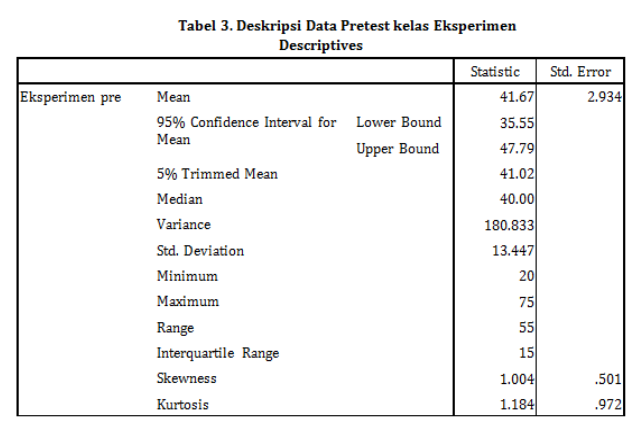

\section{Deskripsi:}

1) Mean atau skor rata-rata dalam pretest kelas eksperimen adalah 41,67. 
2) Median atau skor titik tengah dalam pretest kelas eksperimen adalah 40,0.

3) Skor pretest kelas eksperimen berkisar antara 20-75 dengan range 55 .

4) Standar deviasi atau simpangan baku adalah 13.447.

Rasio Skewness skor pretest kelas eksperimen adalah 1,004 dan kurtosis 1,184. Berdasarkan perbandingan rasio Skewness dan Kurtosis yang berada rentang -2 dan 2. Maka dapat dikatakan data variabel pretest kelas eksperimen memiliki kecenderungan berdistribusi normal.

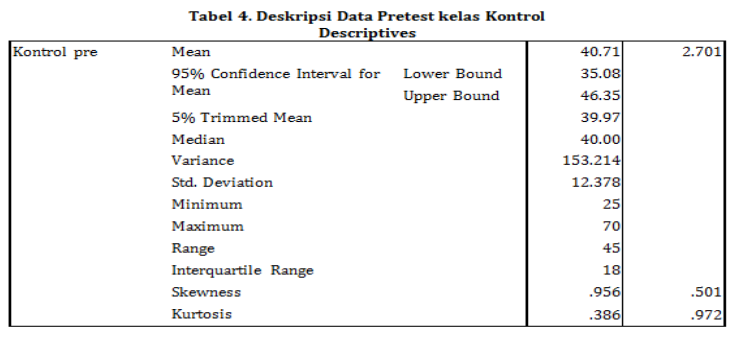

\section{Deskripsi:}

1) Mean atau skor rata-rata dalam pretest kelas kontrol adalah 40.71 .

2) Median atau skor titik tengah dalam pretest kelas kontrol adalah 40.00 .

3) Skor pretest kelas kontrol berkisar antara 25-70 dengan range 45.

4) Standar deviasi atau simpangan baku adalah 12.179.

Rasio Skewness skor pretest kelas kontrol adalah 0.956 dan kurtosis 0.386 . Berdasarkan perbandingan rasio Skewness dan Kurtosis yang berada rentang -2 dan 2. maka dapat dikatakan data variabel pretest kelas kontrol memiliki kecenderungan berdistribusi normal.
Tabel 5 Hasil Uji Normalitas Data Posttest

Kelas Eksperimen dan Kelas Kontrol

\begin{tabular}{|l|c|c|c|c|}
\hline \multicolumn{1}{|c|}{ Kelas } & Sig & A & Keputusan & Ket. \\
\hline Eksperimen & 0,152 & 0,05 & $\mathrm{H}_{0}$ diterima & $\begin{array}{l}\text { Berdistri- } \\
\text { busi normal }\end{array}$ \\
\hline Kontrol & 0,081 & 0,05 & $\mathrm{H}_{0}$ diterima & $\begin{array}{l}\text { Berdistri- } \\
\text { busi normal }\end{array}$ \\
\hline
\end{tabular}

Berdasarkan perhitungan uji normalitas di atas, menunjukkan hasil pretest kelas eksperimen dengan sampel 21 siswa, diperoleh nilai sig $=0,152>0,05$. Jadi $\mathrm{H}_{0}$ diterima, maka data posttest kelas eksperimen berdistribusi normal. Untuk kelas kontrol diperoleh nilai sig 0,081 $\geq$ 0,05 . Jadi $\mathrm{H}_{0}$ diterima, maka data posttest untuk kelas kontrol berdistribusi normal.

Tabel 6. Deskripsi Data Posttest kelas Eksperimen Descriptives
\begin{tabular}{|lll|r|r|}
\hline Eksperimen & Mean & 76.19 & 1.500 \\
post & $95 \%$ Confidence Interval & Lower & 73.06 & \\
& Bound & & \\
& Upper & 79.32 & \\
& Bound & 76.06 & \\
& & 75.00 & \\
& & & \\
& Median & 47.262 & \\
Variance & & 6.875 & \\
Std. Deviation & & 65 & \\
Minimum & 90 & \\
Maximum & 25 & \\
Range & 8 & \\
Interquartile Range & .036 & .501 \\
Skewness & -.325 & .972 \\
Kurtosis & & & \\
\hline
\end{tabular}

\section{Deskripsi:}

1) Mean atau skor rata-rata dalam posttest kelas eksperimen adalah 76.19

2) Median atau skor titik tengahdalam posttest kelas eksperimen adalah 75.00

3) Skor posttest kelas eksperimen berkisar antara 65-90 dengan range 25

4) Standar deviasi atau simpangan baku adalah 6.875

Rasio Skewness skor posttest kelas eksperimen adalah 0.036 dan kurtosis- 
0.325. Berdasarkan perbandingan rasio Skewness dan Kurtosis yang berada rentang -2 dan 2, maka data variabel posttest kelas eksperimen memiliki kecenderungan berdistribusi normal.

Tabel 7. Deskripsi Data Posttest kelas Eksperimen Descriptives
\begin{tabular}{|lll|r|r|}
\hline Kontrolpost & Mean & 69.29 & 2.270 \\
& $95 \%$ Confidence Interval & Lower & 64.55 & \\
for Mean & Bound & 74.02 & \\
& Upper Bound & 7.02 & \\
5\% Trimmed Mean & & 69.48 & \\
Median & 75.00 & \\
Variance & 108.214 & \\
Std. Deviation & 10.403 & \\
Minimum & 50 & \\
Maximum & 85 & \\
Range & 35 & \\
Interquartile Range & 15 & \\
Skewness & -343 & .501 \\
Kurtosis & -.796 & .972 \\
\hline
\end{tabular}

\section{Deskripsi:}

1) Mean atau skor rata-rata dalam posttest kelas kontrol adalah 69.29.

2) Median atau skor titik tengahdalam posttest kelas kontrol adalah 75.00 .

3) Skor posttest kelas kontrol berkisar antara 50-85 dengan range 35.

4) Standar deviasi atau simpangan baku adalah 10.403.

Rasio Skewness skor posttest kelas eksperimen adalah -0.343 dan kurtosis0.796. Berdasarkan perbandingan rasio Skewness dan Kurtosis yang berada rentang -2 dan 2, maka data variabel posttest kelas kontrol berdistribusi normal.

\section{b) Uji Homogenitas}

Uji homogenitas digunakan untuk mengetahui apakah sampel yang diambil mempunyai varians yang homogen atau tidak, dengan taraf signifikansi yang digunakan 5\%. Perumusan hipotesis yang digunakan dalam uji homogenitas data adalah sebagai berikut:
$\mathrm{H}_{0}$ : Varians untuk kedua kelas penelitian homogen

$\mathrm{H}_{1}$ : Varians untuk kedua kelas penelitian tidak homogen

Kriteria pengujiannya adalah Jika nilai signifikansi pengujiannya $\geq$ maka $\mathrm{H}_{0}$ diterima, sedangkan jika nilai signifikansi pengujiannya 0,05 maka $\mathrm{H}_{0}$ ditolak. Uji homogenitas dengan bantuan SPSS 16.

Tabel 8. Hasil Uji Homogenitas Kelas Eksperimen dan Kelas Kontrol

\begin{tabular}{|l|c|c|l|l|}
\hline \multicolumn{1}{|c|}{ Kelas } & sig & A & Keputusan & \multicolumn{1}{|c|}{ Ket. } \\
\cline { 1 - 4 } Eksperimen & \multirow{2}{*}{0,800} & 0,05 & $\mathrm{H}_{0}$ diterima & $\begin{array}{l}\text { Memiliki } \\
\text { varians } \\
\text { Kontrol }\end{array}$ \\
& & & & $\begin{array}{l}\text { yang } \\
\text { sama }\end{array}$ \\
& & & & \\
\hline
\end{tabular}

\section{c) Uji Hipotesis}

Setelah dilakukan uji persyaratan ternyata populasi berdistribusi normal dan homogen untuk kelas eksperimen, kemudian selanjutnya dilakukan uji hipotesis. Pengujian dilakukan untuk mengetahui apakah rata-rata tes siswa kelompok eksperimen yang menggunakan model pembelajaran kooperatif STAD berbantuan media film Situs Astana Gede Kawali lebih tinggi secara signifikan dibanding rata-rata tes kelas kontrol yang menggunakan model konvensional. Pengujian dilakukan dengan menggunakan uji-t. Perumusan hipotesis yang digunakan dalam uji-t adalah:

$\mathrm{H}_{0}: \mu_{1}=\mu_{2}$

$\mathrm{H}_{1}: \mu_{1}>\mu_{2}$ $\mu_{1}$ : rata-rata tes siswa kelas eksperimen $\mu_{2}$ :rata-rata tes siswa kelas kontrol

Kriteria pengujiannya adalah sebagai berikut: 
Jika nilai signifikansi $\geq 0,05, \mathrm{H}_{0}$ diterima Jika nilai signifikansi $<0,05, \mathrm{H}_{0}$ ditolak

$$
\text { Untuk mengetahui perbedaan }
$$
pengaruh model pembelajaran kooperatif STAD berbantu media film Situs Astana Gede Kawali terhadap hasil belajar dan kesadaran sejarah siswa dilakukan uji-t menggunakan uji statsitik Compare Mean Independen Sample Test.

Tabel 9. Hasil Uji Hipotesis (Uji-t) Data Pretest Kelas Eksperimen dan Kelas Kontrol

\begin{tabular}{|l|l|l|l|l|}
\hline Kelas & Sig & A & Keputusan & Ket \\
\hline $\begin{array}{l}\text { Eksperi- } \\
\text { men }\end{array}$ & 0,812 & 0,05 & $\mathrm{H}_{0}$ diterima & $\begin{array}{l}\text { Terdapat } \\
\text { perbedaan }\end{array}$ \\
\cline { 1 - 1 } Kontrol & 0, & & \\
\hline
\end{tabular}

Berdasarkan tabel 9 diperoleh nilai signifikansi (2-tailed) 0,812>0,05 maka $\mathrm{H}_{0}$ diterima. Artinya rata-rata skor pretest siswa antara kelas eksperimen dan kelas kontrol sama atau tidak terdapat perbedaan. Hal ini menunjukan kemampuan tes siswa kelas eksperimen dan kontrol memiliki kemampuan sama.

Selanjutnya, tabel 10 menunjukkan nilai signifikansi (2-tailed) $0,015<0,05$, maka $\mathrm{H}_{0}$ ditolak atau $\mathrm{H}_{1}$ diterima. Artinya terdapat perbedaan hasil skor antara kelas eksperimen dan kelas kontrol.

Tabel 10. Hasil Uji Hipotesis (Uji-t) Data Pretest Kelas Eksperimen dan Kelas Kontrol

\begin{tabular}{|l|c|c|c|l|}
\hline \multicolumn{1}{|c|}{ Kelas } & Sig & A & Keputusan & \multicolumn{1}{|c|}{ Ket. } \\
\hline $\begin{array}{l}\text { Eksperi- } \\
\text { men }\end{array}$ & 0,015 & 0,05 & $\mathrm{H}_{0}$ ditolak & $\begin{array}{l}\text { Tidak } \\
\text { terdapat } \\
\text { perbedaan }\end{array}$ \\
\cline { 1 - 3 } & & & & \\
\hline
\end{tabular}

\section{d) Analisis Data Sikap Siswa}

Data sikap siswa diperoleh dari angket yang dibagikan dan diisi oleh siswa. Skala yang digunakan adalah skala Likert.
Sigular dan Dadang (dalam Sunaryo, 2013: 71) menyatakan Jika pernyataan yang diberikan mendukung sikap positip, maka nilai jawaban sebagai berikut $S S=4, S=3$, $\mathrm{TS}=2$, dan $\mathrm{STS}=1$, tetapi jika pernyataannya mendukung sikap negatif, maka nilai setiap jawaban adalah kebalikannya, yaitu: $\mathrm{SS}=1, \mathrm{~S}=2, \mathrm{TS}=3$, dan $\mathrm{STS}=4$.

Lebih lanjut, Sugilar dan Dadang (dalam Sunaryo, 2013: 72) menyatakan bahwa responden boleh sedikit digiring untuk setuju atau tidak setuju, dalam hal ini pilihan $\mathrm{N}$ tidak disertakan, responden hanya diminta memilih SS, S, TS, dan STS dan jawaban netral tidak digunakan untuk mendorong siswa menentukan keberpihakan dalam menjawab.

Penggolongan kelompok siswa yang memiliki sikap negatif dan sikap positif dilakukan dengan membandingkan rerata skor subjek dengan rerata skor jawaban netral. Pada penelitian ini skor netralnya adalah median dari skor angket yang berskala 4. Uraian proses penentuan skor netral sebagai berikut:

$$
\text { Skor netral }=\underline{1+2+3+4}=2,5
$$

(Diadaptasi dari Sunaryo, 2013: 72)

Menurut Suherman dan Yahya (dalam Sunaryo 2013: 72) cara menentukan sikap siswa, yaitu jika rerata skor siswa lebih besar atau sama dengan rerata skor netral, maka sikap siswa positif, sedangkan jika rerata skor siswa kurang dari rerata skor netral, sikap siswa negatif. 
B. Pengaruh Kesadaran Sejarah Terhadap Hasil Belajar Siswa

1. Model Summary

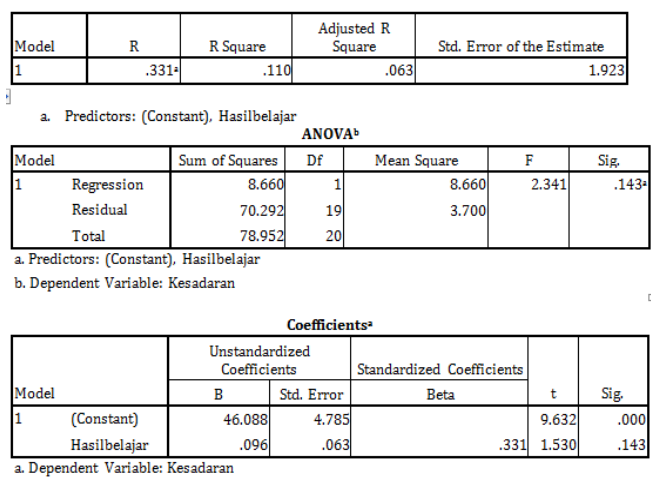

Analisa:

a) Kolom $\mathrm{R}$ di Table Model Summary adalah koefisien korelasi Prearson $(0,331)$ yang menunjukan tingkat hubungan yang sedang antara kesadaran sejarah dan hasil belajar.

b) Kolom $\mathrm{R}$ Square di table Model Summary menunjukan nilai kesadaran sejarah mempengaruhi hasil belajar siswa sebesar 0,110 atau $11 \%$.

c) Tabel ANOVA memaparkan uji kelinearan. Dalam hal ini, Asym Sig $(0,143)>\alpha(0,05)$, maka $\mathrm{H}_{0}$ diterima. Jadi tidak terdapat hubungan linear antara kesadaran sejarah dan hasil belajar siswa. Hal ini tidak terdapat pengaruh positif nilai kesadaran sejarah dan hasil belajar.

d) Tabel Coefficients memaparkan uji koefisien. Asymp Sig $(0,000)<\alpha(0,05)$, maka $\mathrm{H}_{0}$ ditolak. Jadi koefisien regresi signifikan.

e) Persamaan Regresi: $Y=46,088+0,096 \mathrm{X}$.
Penutup

\section{A. Kesimpulan}

Berdasarkan hasil analisis dan pengujian terhadap hipotesis yang dilakukan bahwa Pertama, hasil penelitian menunjukan terdapat perbedaan yang signifikan hasil belajar dan kesadaran sejarah siswa yang menggunakan model pembelajaran kooperatif STAD berbantuan media film Situs Astana Gede Kawali dengan siswa yang tidak menggunakan model pembelajaran kooperatif STAD berbantuan media film Situs Astana Gede Kawali. Kedua, adanya pengaruh kesadaran sejarah terhadap hasil belajar siswa.

Dengan demikian, pembelajaran menggunakan model pembelajaran kooperatif berbantuan media film Situs Astana Gede Kawali sebagai salah satu peninggalan sejarah yang ada di kabupaten Ciamis lebih baik hasilnya dibandingkan dengan pembelajaran yang hanya menggunakan model/metode.

\section{B. Saran}

Berdasarkan hasil penelitian dapat dikemukakan beberapa saran, yaitu Pertama, Guru Sejarah sebaiknya memperhatikan model dan media pembelajaran yang digunakan, yaitu model yang banyak menuntut siswa untuk aktif, sedangkan guru hanya sebagai fasilitator dan motivator. Salah satunya adalah model pembelajaran Student Teams Achievement Division. Guru harus mampu 
memperkenalkan sejarah lokal lingkungan sekitar melalui kegiatan pembelajaran dengan menggunakan media film.

Kedua, untuk penelitian selanjutnya dengan melihat film situs sejarah lokal dapat meningkatkan kesadaran sejarah dan hasil belajar siswa, maka penggunaan media dapat digabung dengan penggunaan model yang sesuai dengan mengkaitkan aspek-aspek yang belum diungkap dan dikembangkan.

\section{Daftar Pustaka}

- Tanpa Tahun. Kesadaran Sejarah Dalam Pendidikan Sejarah.

Adisusilo, Sutarjo. 2011. Pembelajaran Nilai-Nilai Karakter. Jakarta: PT. Rajagrafindo Persada.

Aman. 2014. Aktualisasi Nilai-Nilai Kesadaran Sejarah dan Nasionalisme Dalam Pembelajaran Sejarah Di SMA. Jurnal Pendidikan Karakter, Tahun IV, Nomor 1, Februari 2014.

Anderson, Ronald H. 1987. Pemilihan dan Pengembangan Media Untuk Pembelajaran. Jakarta: CV. Rajawali.

Aqib, Zainal. 2013. Model-model, Media dan Strategi Pembelajaran Kontekstual (Inovatif).Bandung: Yrama Widya.

Ghufron, Anik. 2008. Metodologi Penelitian Kuantitatif. Fakultas Ilmu Pendidikan UNY.

Hasan, S. Hamid. Tanpa Tahun. Problematika Pendidikan Sejarah. Bandung: FPIPS UPI

Huda, Miftahul. 2013. Cooperative Learning: Metode, Teknik, Struktur dan Model Terapan. Yogyakarta: Pustaka Pelajar.

Kartodirdjo, Sartono. 1993. Pendekatan Ilmu Sosial dalam Metodologi Sejarah. Jakarta: Gramedia Pustaka Utama.
Pajriah, Sri. 2012. Pengaruh Model Dual Coding Terhadap Peningkatan Hasil Belajar Siswa Pada Mata Pelajaran Sejarah (Studi Penelitian Kuasi Eksperimen pada Siswa Kelas XI di SMAN 1 Ciamis). Tesis Pascasarjana UPI Bandung: tidak diterbitkan.

Rusman. 2012. Model-model Pembelajaran. Jakarta: PT. Raja Grafindo Persada.

Sadiman, Arif S, dkk. 1984. Media Pendidikan. Jakarta: PT. Raja Grafindo Persada.

Soedarmo, Runalan. 2011. Pelestarian Benda Cagar Budaya dan Upaya Pengembangan Nilai Budaya Situs Astana Gede Sebagai Warisan Peninggalan Sejarah di Kecamatan Kawali Kabupaten Ciamis. Cakrawala Galuh Vol. I No. 6 September 2011.

Soedjatmoko. 1984. Dimensi Manusia dalam Pembangunan: Pilihan Karangan. Jakarta: Lembaga Penelitian, Pendidikan, dan Penerangan Ekonomi dan Sosial.

Subakti, YR. 2010. Paradigma Pembelajaran Sejarah Berbasis Konstruktivisme. SPPS, Vol. 24, No. 1, April 2010.

Sugiyono. 2012. Metode Penelitian Pendidikan Pendekatan Kuantitatif, Kualitatif, dan R\&D. Bandung: Alfabeta.

Sunaryo, Yoni. 2013. Implementasi Model Pembelajaran Berbasis Masalah Untuk Meningkatkan Kemampuan Berfikir Kritis dan Kreatif Siswa SMA di Kota Tasikmalaya. Tesis. Universitas Terbuka: Tidak Diterbitkan.

Suryana, Aan. 2015. Penerapan Model Pembelajaran Student Teams Achievment Division (STAD) Dengan Film Dokumenter Tentang Materi Pembelajaran Pendudukan Jepang di Indonesia Untuk Meningkatkan Motivasi Belajar dan Kesadaran Sejarah (Penelitian Tindakan Kelas Pada Siswa SMA Plus Informatika 
Ciamis). Tesis. Pascasarjana UNS

Surakarta: tidak diterbitkan.

Thabrani, Muhammad \& Arif Mustofa. 2011. Belajar \& Pembelajaran. Jakarta: Ar Ruzi Media.

Trianto. 2007. Model-Model Pembelajaran Inovatif Berorientasi Konstruktivistik. Jakarta: Prestasi Pustaka Publisher.

Warsito. 2012. Antropologi Budaya. Yogyakarta: Penerbit Ombak.

Wiyanarti, Erlina. Tanpa Tahun. Model Pembelajaran Kontekstual Dalam Pengembangan Pembelajaran Sejarah. Bandung: FPIPS UPI. 